\title{
Levantamento de manifestações patologicas da Catedral Paróquia Nossa Senhora da Penha
}

\author{
I. Feitosa ${ }^{1 *}$, J. Bezerra ${ }^{2 *}$, L. Rodrigues ${ }^{3 *}$, N. Rodrigues ${ }^{4^{*}}$ \\ *Ivna Feitosa Alencar: ivna.feitosa@aluno.ufca.edu.br \\ *José Eduardo Bezerra de Sousa: jose.eduardo@aluno.ufca.edu.br \\ *Lidice Maria Rodrigues Siebra: lidicesiebra.ec@gmail.com \\ * Nelson Matheus Rodrigues Ferraz de Alencar:nelson.matheus@aluno.ufca.edu.br \\ 1 Graduanda, curso de Engenharia Civil, Crato, Brasil. \\ 2 Graduando, curso de Engenharia Civil, Juazeiro do Norte, Brasil. \\ 3 Graduanda, curso de Engenharia Civil, Caririaçu, Brasil. \\ 4 Graduando, curso de Engenharia Civil, Crato, Brasil.
}

\begin{abstract}
RESUMO
A Sé Catedral Nossa Senhora da Penha foi o primeiro templo católico erguido na cidade de Crato. Considerando sua importância, o objetivo do trabalho é realizar um levantamento das patologias encontradas na edificação. Mesmo diante das dificuldades existentes pela pandemia, desenvolveuse uma metodologia, baseada em um estudo de caso, pautada em cinco abordagens: planejamento das atividades, estudo do assunto, pesquisa na região, visita à edificação históricas e produção textual. Dessarte, levantou-se as ocorrências das patologias apresentadas por intermédio de imagens e descrições. Percebeu-se grande incidência de fissuras, empolamentos e eflorescências, os quais correspondem a 73,68\% do total. Assim, sugerem-se possíveis causas e soluções para cada problema, bem como estímulo à trabalhos técnico-científicos de carácter analíticos para a região do Cariri.
\end{abstract}

Palavras chave: Patologias; Igreja da Sé; levantamento; estudo de caso. 


\begin{abstract}
The Cathedral of Nossa Senhora da Penha was the first Catholic church built in the city of Crato. Considering its importance, the objective of the work is to carry out a survey of the pathologies found in the building. Even in the face of the existing difficulties caused by the pandemic, a methodology was developed, based on a case study, based on five approaches: activity planning, study of the subject, research in the region, visit to the historical building and textual production. Thus, the occurrences of pathologies presented through images and descriptions were raised. There was a high incidence of cracks, blisters and efflorescence, which correspond to $73.68 \%$ of the total. Thus, possible causes and solutions for each problem are suggested, as well as encouragement of technical-scientific works of an analytical nature for the Cariri region.
\end{abstract}

Keywords: Pathologies; Igreja da Sé; survey; case study.

\title{
RESUMEN
}

La Catedral de Nossa Senhora da Penha fue la primera iglesia católica construida en la ciudad de Crato. Considerando su importancia, el objetivo del trabajo es realizar un relevamiento de las patologías encontradas en el edificio. Incluso ante las dificultades existentes provocadas por la pandemia, se desarrolló una metodología, a partir de un estudio de caso, con base en cinco enfoques: planificación de actividades, estudio del tema, investigación en la región, visita al edificio histórico y producción textual. Así, se plantearon las ocurrencias de patologías presentadas a través de imágenes y descripciones. Hubo una alta incidencia de grietas, ampollas y eflorescencias, que corresponden al 73,68\% del total. Así, se proponen posibles causas y soluciones para cada problema, así como el fomento de trabajos técnico-científicos de carácter analítico para la región de Cariri.

Palabras clave: Patologías; Igreja da Sé; encuesta; estudio de caso.

\section{INTRODUÇÃO}

A Sé Catedral Nossa Senhora da Penha, conhecida como Igreja da sé, foi o primeiro templo católico erguido na cidade de Crato, no estado do Ceará, teve o início da sua construção como igreja matriz no ano de 1745, passando por vários desgastes na sua vida útil, sendo necessárias reformas pontuais na sua estrutura até 1914, onde foi nomeada catedral (Instituto Brasileiro de Geografia e Estatística, 2021). Palco de muitos eventos sociais prestigiados por pessoas de toda a região do Cariri, a catedral é espaço de significativa mobilidade social, sendo necessário amparo estrutural suficiente para prover a segurança e conforto de todos os usuários. Tendo em vista esse contexto, vale destacar o valor de análises das ocorrências patológicas de tal edificação, sendo imprescindível o conhecimento das origens do problema, histórico da edificação a fim de resguardar o valor da vida e a consciência sociocultural da catedral.

Assim, ao datar do início da vida humana, denota-se que o conhecimento de engenharia civil se faz fundamental a qualidade de vida populacional, o qual, ao longo do tempo, cresceu em complexidade e demanda tecnológica. Tal crescimento exacerbado da construção civil, provocou a necessidade de inovações que trouxeram, em si, a aceitabilidade implícita de maiores riscos, ainda que dentro de certos limites, os quais alavancaram a necessidade de um maior conhecimento sobre estruturas e materiais, através de análises dos erros acontecidos, os quais resultam em deterioração precoce ou até acidentes incisivos à vida humana (Souza e Ripper, 1998). As manifestações patológicas são ocasionadas por uma ou mais falhas oriundas de pelo menos uma etapa do processo 
de construção (Pacheco e Titikian, 2013). Tal equívoco reflete na seguridade, degradação estética e funcional da edificação.

Assim, o referente trabalho tem como objetivo contribuir com o meio técnico-científico, através da difusão do conhecimento acerca das análises e levantamentos patológicos encontrados na edificação da Sé Catedral Nossa Senhora da Penha, considerando o papel do profissional da engenharia, ancorado no desenvolvimento harmônico entre o ser humano e seu ambiente (Conselho Federal de Engenharia e Agronomia, 2019).

\section{PROCEDIMIENTO}

O trabalho em questão é um estudo de caso. De acordo com o que ensina Yin (2001), dentre as diferentes formas de realizar uma pesquisa, o estudo de caso é uma investigação empírica e abrangente, na qual é desenvolvida quando o fato atual está imerso dentro de uma realidade real vivenciada, havendo pouco ou nenhum controle sobre o evento (p. 32 e 33).

A Paróquia da Sé Catedral Nossa Senhora da Penha está compreendida na Região Metropolitana do Cariri, localizada no centro do município do Crato, extremo-sul do estado do Ceará, Brasil.
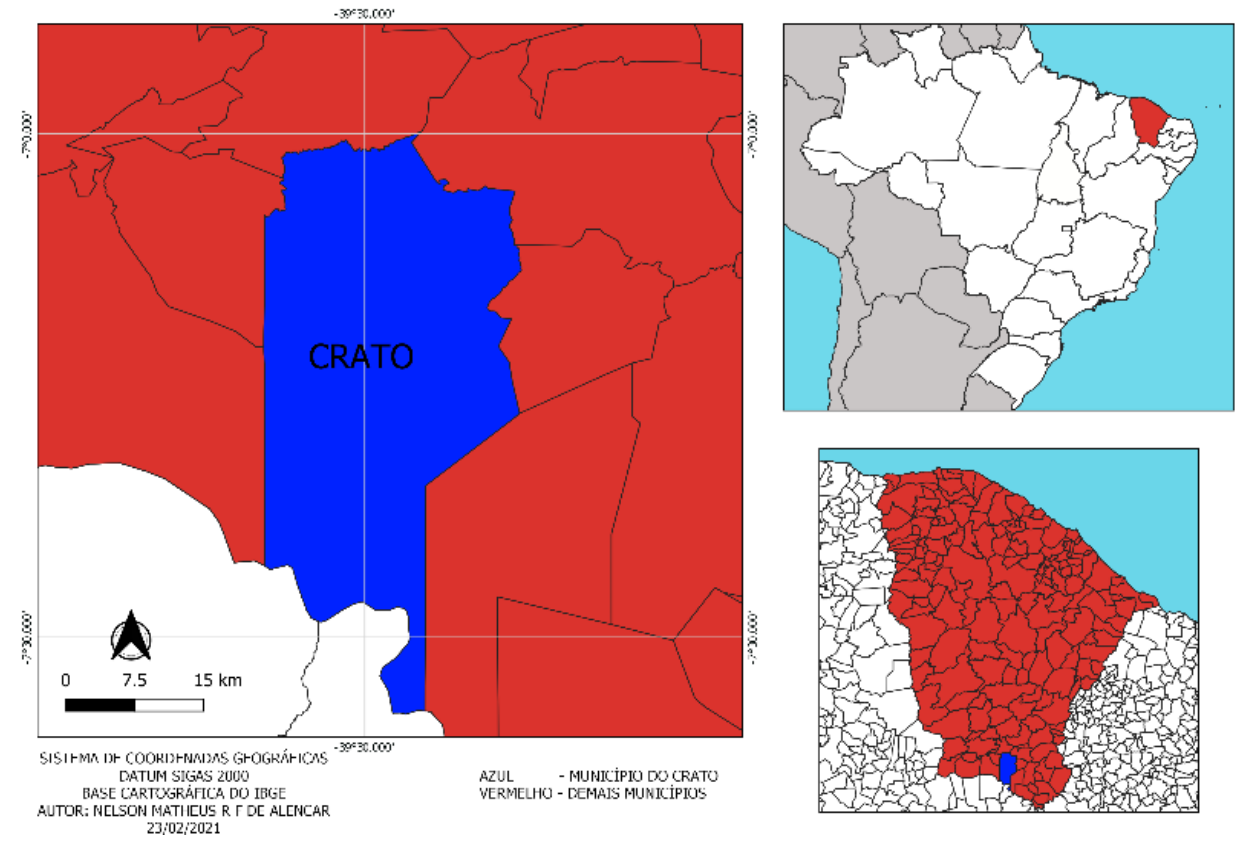

Figura 1. Mapa limites da cidade do Crato

Fonte: Os autores, 2021. 


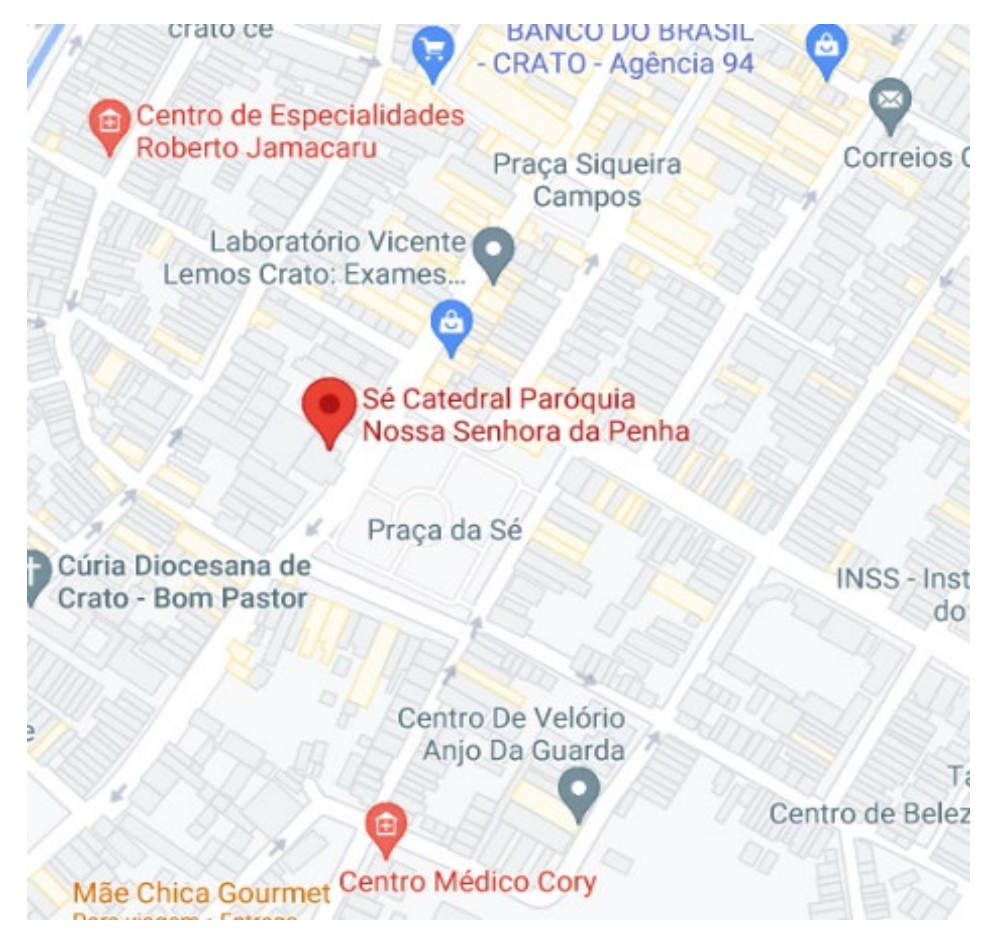

Figura 2. Mapa de localização da Sé Catedral Paróquia Nossa Senhora da Penha Fonte: Google Maps, 2021.

Dentre a metodologia abordada, destacam-se 5 pontos essenciais para realização do estudo de caso referente às patologias em monumentos históricos na região do Cariri.

$\mathrm{Na}$ etapa de planejamento, foi organizado um cronograma a ser implementado para fomentar o desenvolvimento do artigo, no qual foram delimitados os principais procedimentos a serem realizados: o estudo, a pesquisa, as visitas e a produção.

$\mathrm{Na}$ etapa do estudo, recorreu-se a uma gama de artigos, revistas, livros e sites sobre as principais patologias encontradas em monumentos históricos em todo o território brasileiro, procedimento de identificação das anomalias, suas principais causas e os efeitos ocasionados pelo mesmo.

$\mathrm{Na}$ etapa da pesquisa, realizou-se buscas sobre informações acerca do histórico de reformas no patrimonio paroquial, consultando o Padre José Vicente. No qual, foram realizados alguns questionamentos, dentre eles: a) Quando ocorreu a última reforma? b) Como era a estructura antes da última reforma?

Na etapa da visita, a partir dos dados levantados, realizou-se a visita em várias edificações, obtendo êxito na Paróquia Sé Catedral Nossa Senhora da Penha, na qual o Pároco Pe. José Vicente Pinto de Alencar Silva em sua grande maestria explicou sobre a historicidade da Catedral e concedeu a permissão para realização de fotografias da paróquia.

$\mathrm{Na}$ etapa da produção, reuniu-se todo o material e analisou-se todas as patologias encontradas, realizando sua identificação quanto ao tipo, ao tamanho e a sua abrangência na edificação. Com base nisso, determinou-se os ambientes mais acometidos e possíveis agentes causadores dessas problemáticas. 


\section{RESULTADOS}

Foram catalogadas as patologias encontradas nas estruturas do edifício Sé Catedral Paróquia Nossa Senhora da Penha (Igreja da Sé), por intermédio de visitas ao local. Dessa forma, o levantamento do resultado se dará por meio de registros de imagens feitas no ambiente e visualização em tabela das patologias registradas.

\section{1- Fachada}

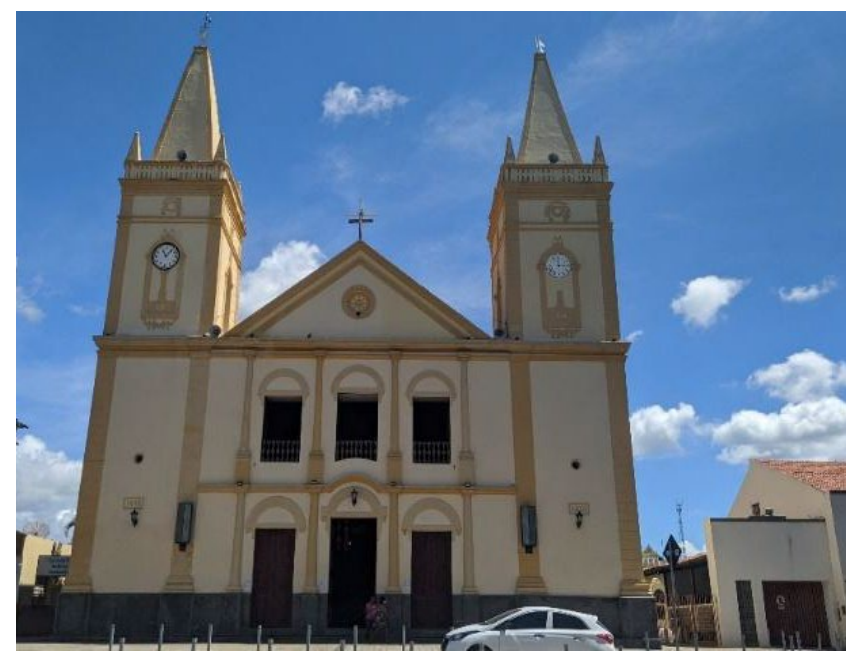

Figura 3. Vista frontal da fachada do ed 1

Fonte: Os autores, 2021. 1

3.1.1 - Parede ao redor da porta de entrada principal.

Presença de fissura na parte superior. (Figura 4) Ocorrência de descolamento com empolamento, na parte lateral direita da parede externa próxima a porta. (Figura 5)

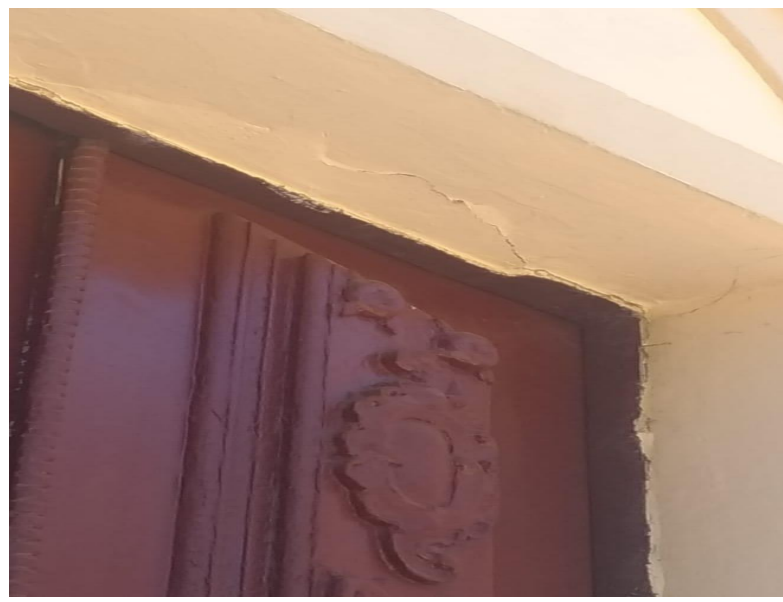

Figura 4- Parte superior da parede próxima à porta. Patologia: fissura Fonte - Os autores, 2021.

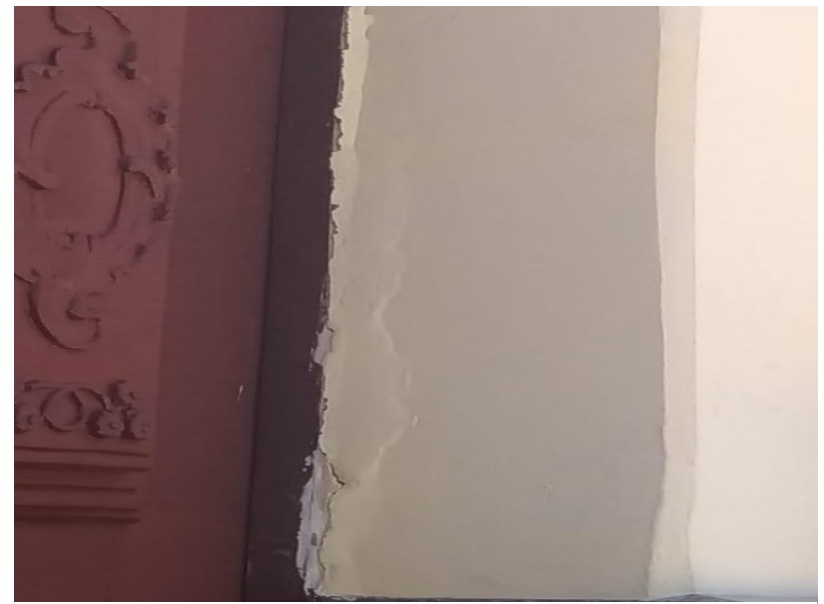

Figura 5- Parte superior da parede próxima à porta da entrada principal. Patologia:

Empolamento

Fonte - Os autores, 2021 
3.1.2- Porta da entrada principal

Porta de material não adequado ao local, devido a exposição à umidade. (Figura 6)

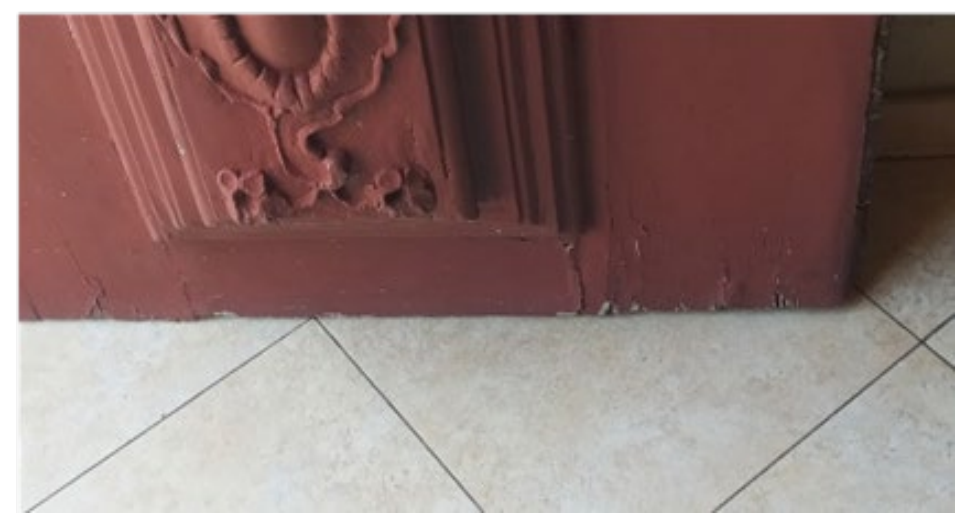

Figura 6- Porta da entrada principal. Patologia: Presença de umidade na parte inferior da porta. Fonte - Os autores, 2021

\subsection{3- Fachada principal}

Presença de eflorescência, causando descascaramiento de pintura (Figura 7). Presença de fissura diagonal no granito, região inferior da parede (Figura 8) Presença de infiltração e empolamento na pintura, causando o aparecimento de manchas escurecidas, bolhas e descascamentos (Figura 9).

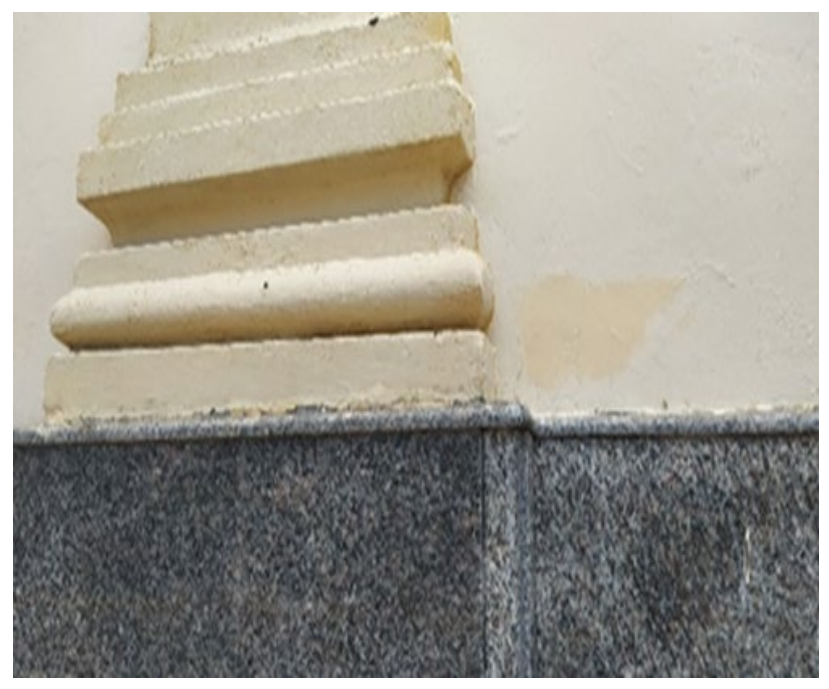

Figura 7- Parede da vista frontal da fachada. Lado esquerdo. Patologia: eflorescencia. Fonte - Os autores, 2021

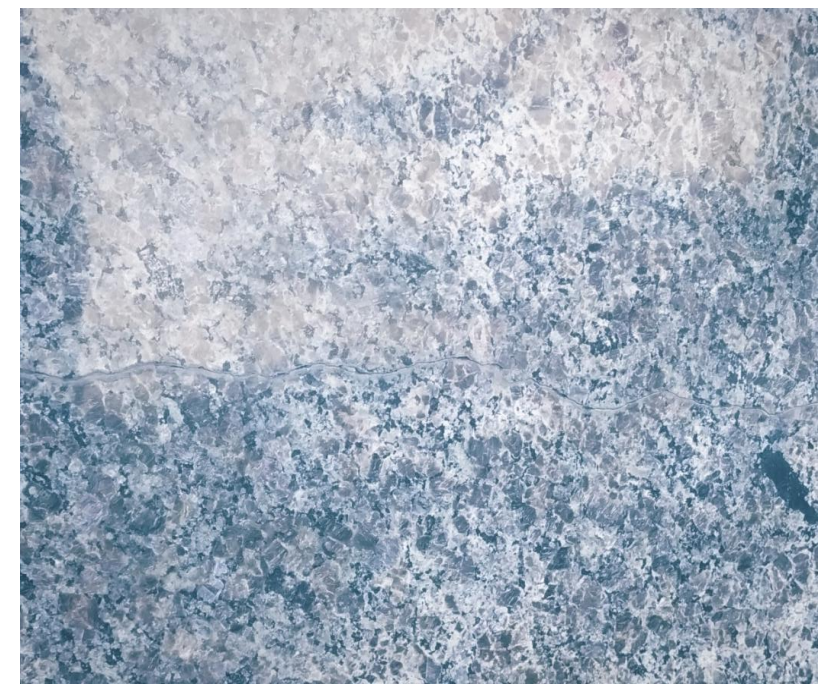

Figura 8- Região inferior da parede, no granito. Lado esquerdo as três portas principais. Patologia: Fissura Fonte: Os autores, 2021. 


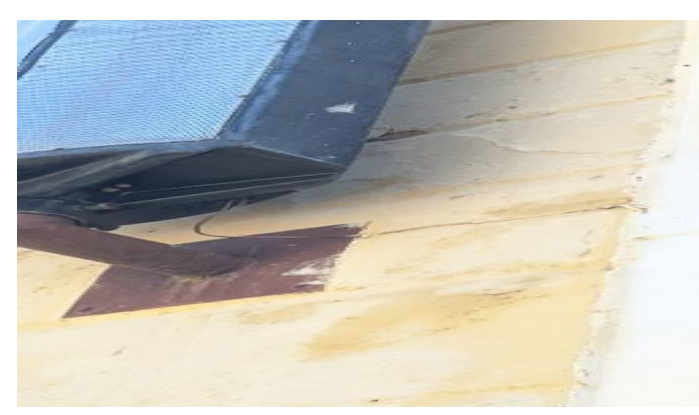

Figura 9- Parede da vista frontal da fachada. Lado esquerdo. Patologia: Empolamento da pintura e infiltração.

Fonte: Os autores, 2021.

3.1.4- Vista frontal da fachada.

Presença de manchas de bolor na janela e na parte superior a ela.

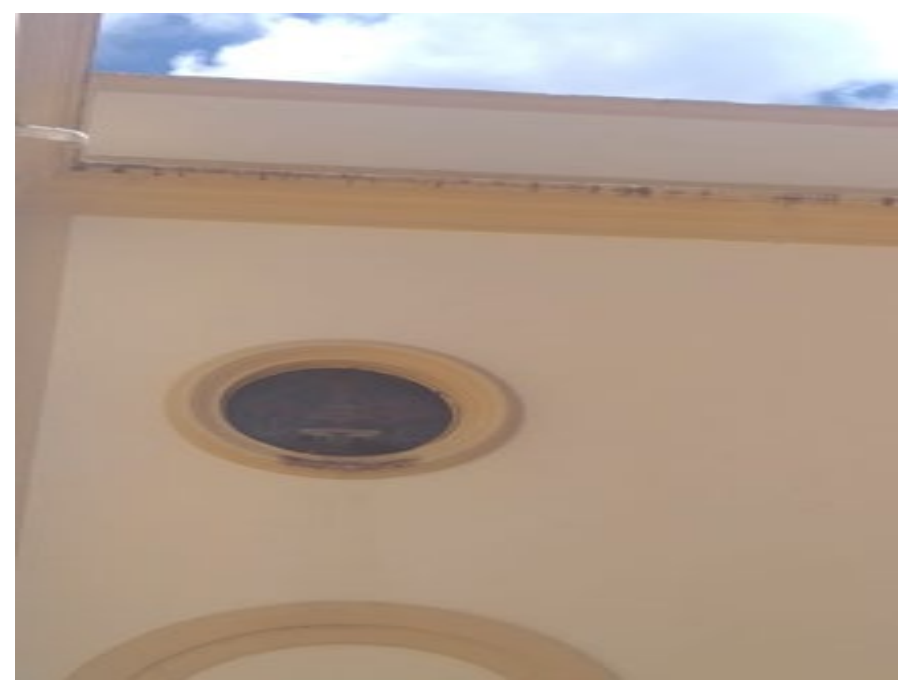

Figura 10- Parede da parte lateral da fachada, acima da porta secundária. Lado direito. Patologia:

Manchas de bolor.

Fonte: Os autores, 2021.

3.1.4- Vista lateral esquerdo da fachada

Ocorrência de saponificação, causando descascamento da pintura e aparecimento do revestimento de reboco.(Figura 11)

Presença de fissura vertical na região inferior da parede. (figura 12) 

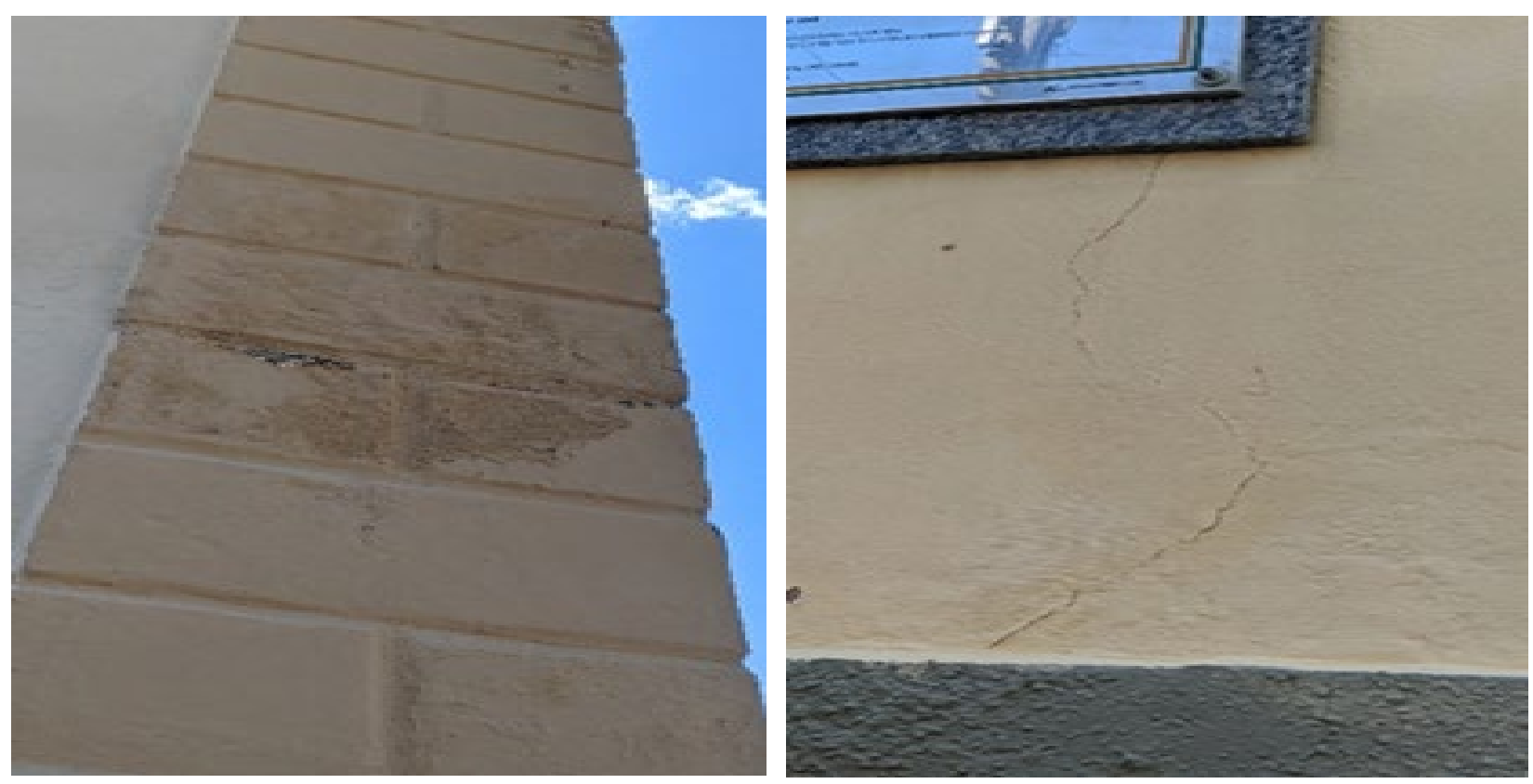

Figura 11- Parede da vista esquerdo frontal. direito da parede, no canto superior. Patología: Saponificação.

Figura 12- parede lateral da fachada, na região inferior a parede. Patologia: fissura Fonte: Os autores, 2021.

Fonte: Os autores, 2021.

3.2- Estrutura interna do edifício

3.2.1- Parede próxima a entrada principal

Ocorrência de fissura diagonal (Figura 13 e 14).

Ocorrência de infiltração (Figura 15).

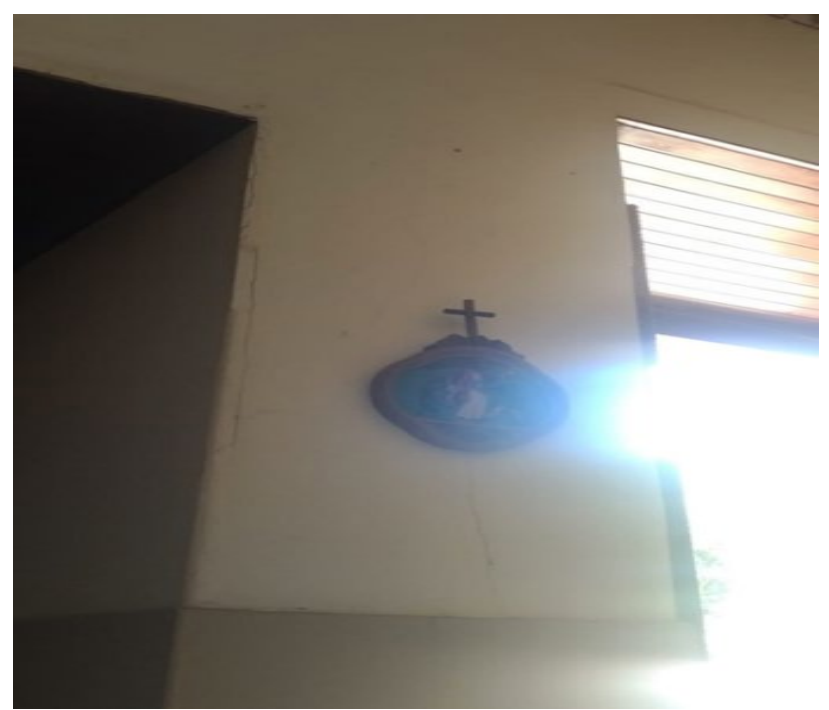

Figura 13- Parede entre as portas de entrada.

Lado esquerdo. Patologia: fissura

Fonte: Os autores, 2021.

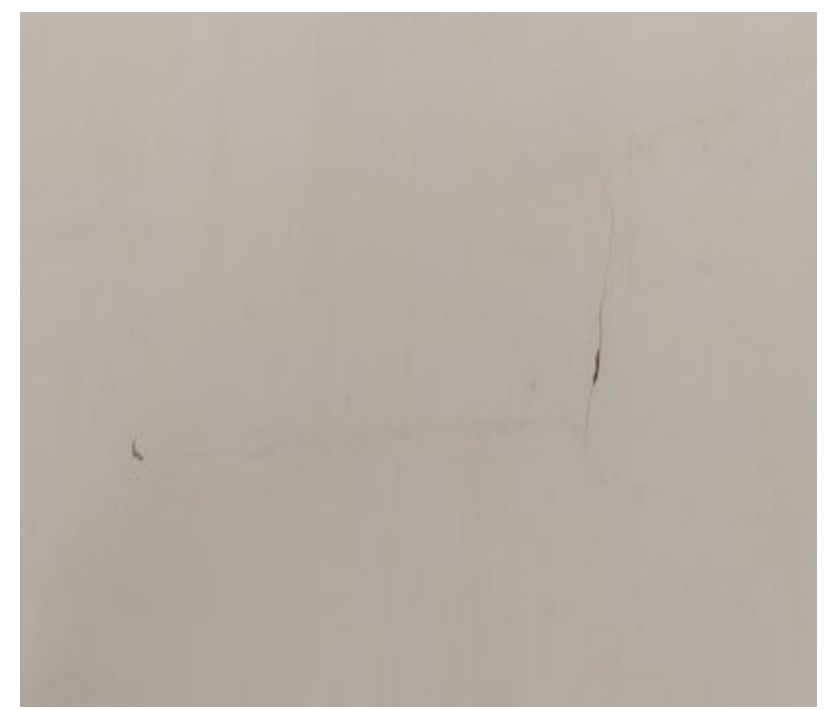

Figura 14- Parede do lado direito das portas principais. Patologia: fissura Fonte: Os autores, 2021. 


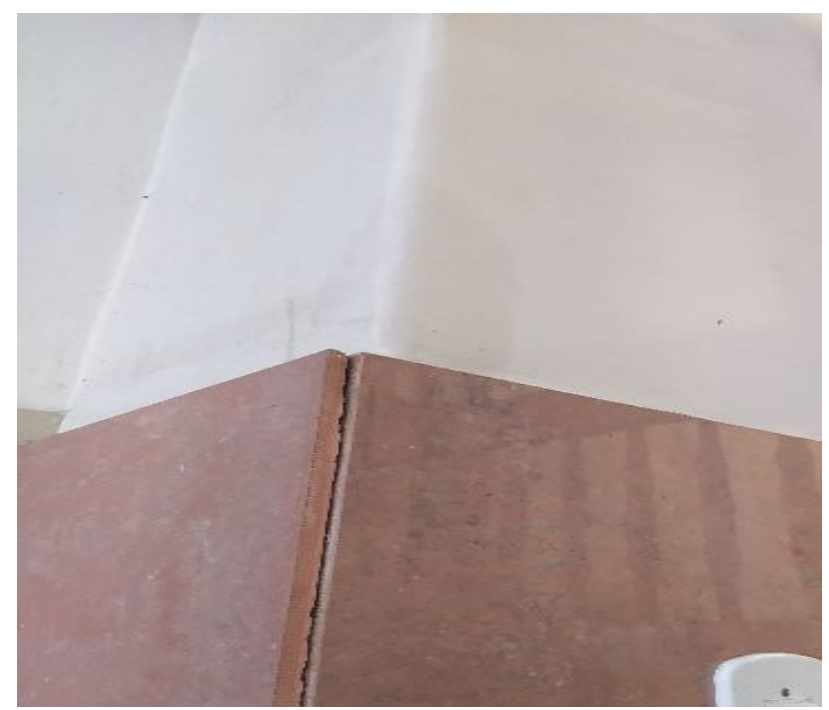

Figura 15- Parede próxima a entrada principal e à entrada do local de batismo. Patologia: infiltração

Fonte: Os autores, 2021.

\subsection{2- Local de batismo}

Presença de empolamento da pintura e infiltração, devido a umidade, causando mancha na pintura e a descamação

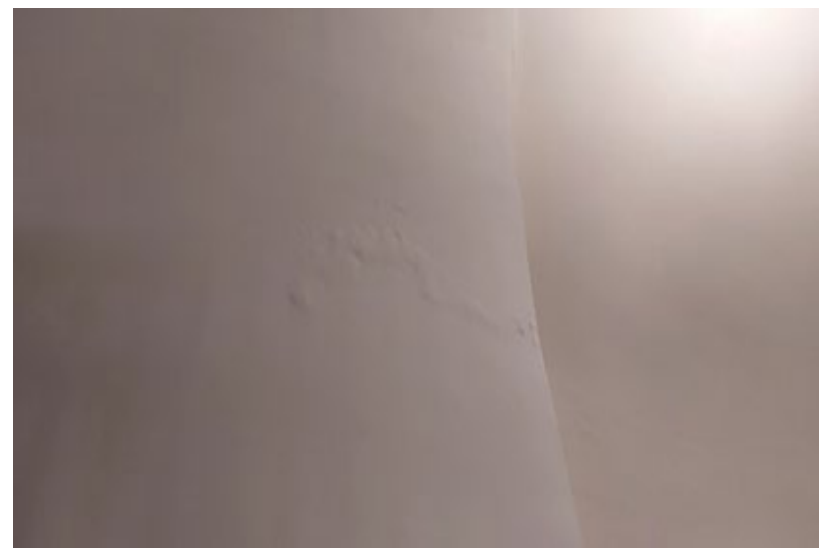

Figura 16- Parede da lateral esquerda do cômodo de batismo. Patologia: Empolamento da pintura e infiltração Fonte: Os autores, 2021.

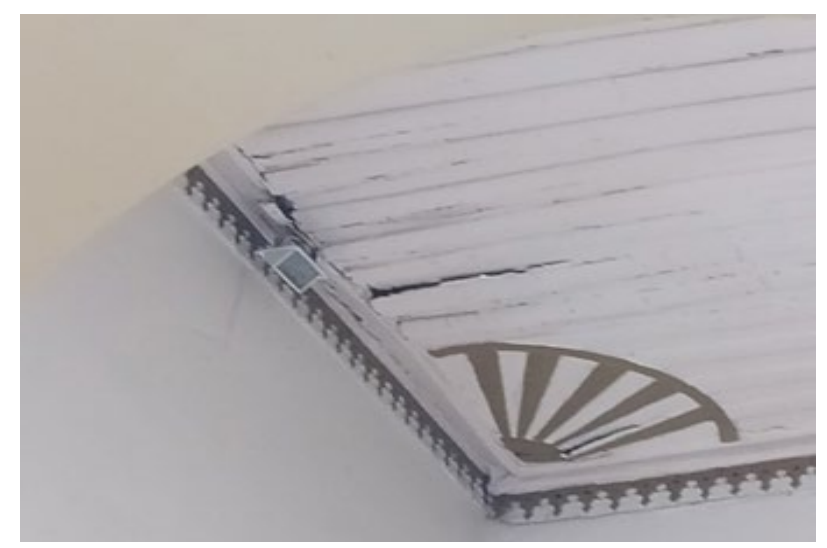

Figura 17 - Forro de madeira da parte lateral direita da igreja. Patologia: infiltração Fonte: Os autores, 2021.

\subsection{3- Parede divisória da parte interna}

Ocorrência de fissura (Figura 18).

Ocorrência de desprendimento e empolamento da placa cerâmica, tonando visível a estrutura de revestimento: o reboco (Figura 19). 


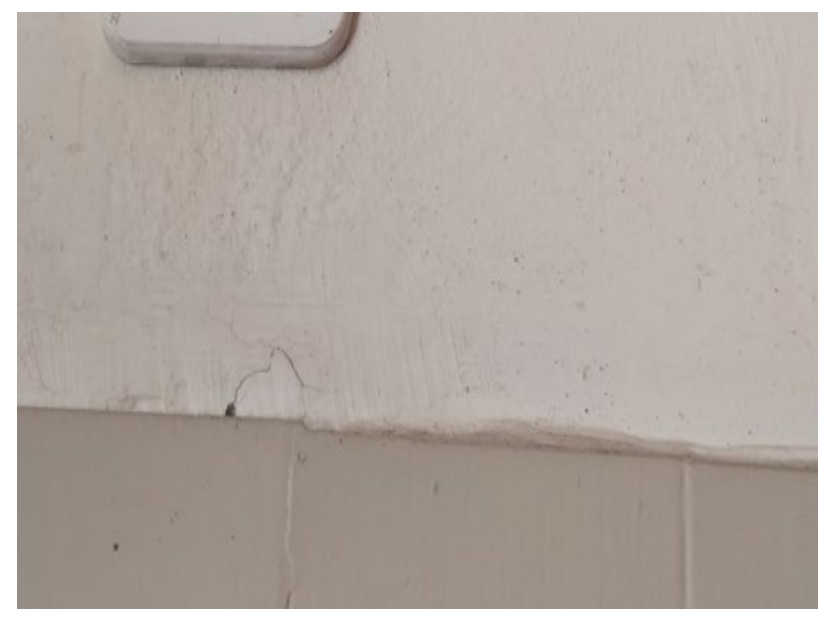

Figura 18- Parede do lado direito, segunda vista frontal. Patologia: fissura. Fonte: Os autores, 2021.

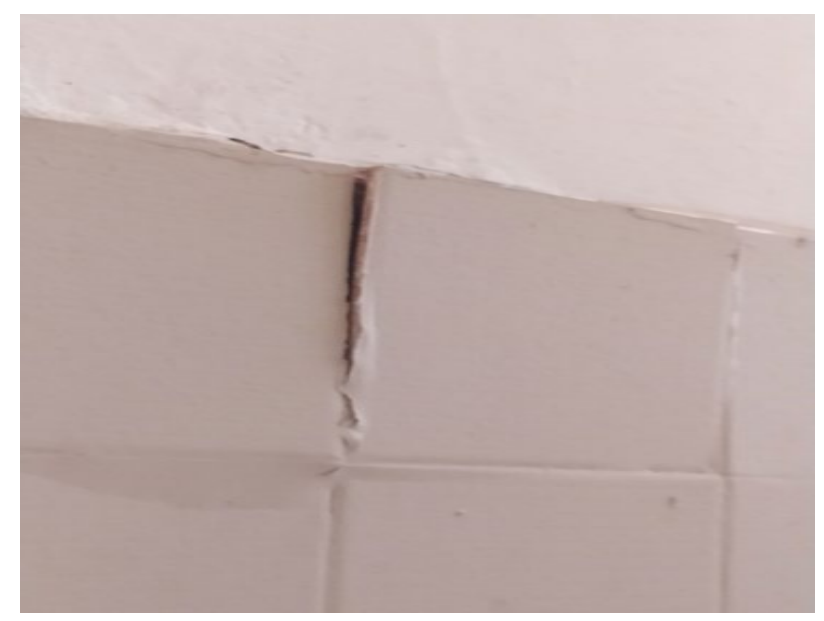

Figura 19- Parede do lado direito, segundo vista frontal. Lado direito da parede.Patologia:

Desprendimento e empolamento de revestimento de peça cerâmica

Fonte: Os autores, 2021.

3.2.4- Parede do lado direito da estrutura.

Empolamento da pintura, causando bolhas entre as camadas de trinca e o reboco (Figura 20). Ocorrência de trinca, fissuras e aparecimento de eflorescência, causando manchas brancas e o descolamento da pintura (Figura 21)

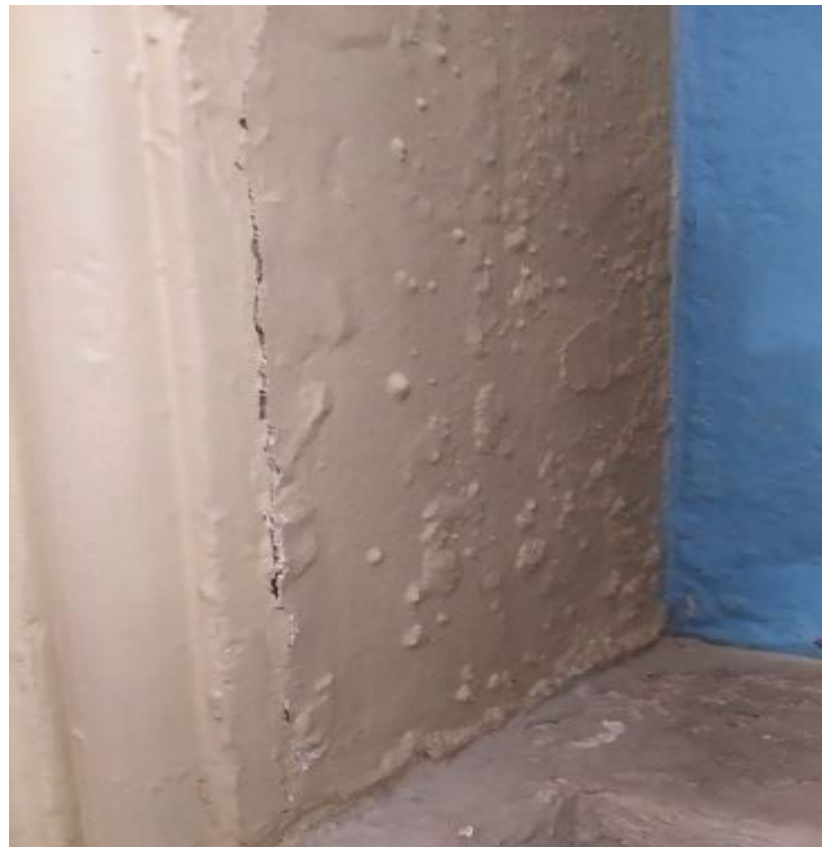

Figura 20- Parede do lado direito, segunda vista frontal. Lado direito da parede.Patologia: Desprendimento Fonte: Os autores, 2021.

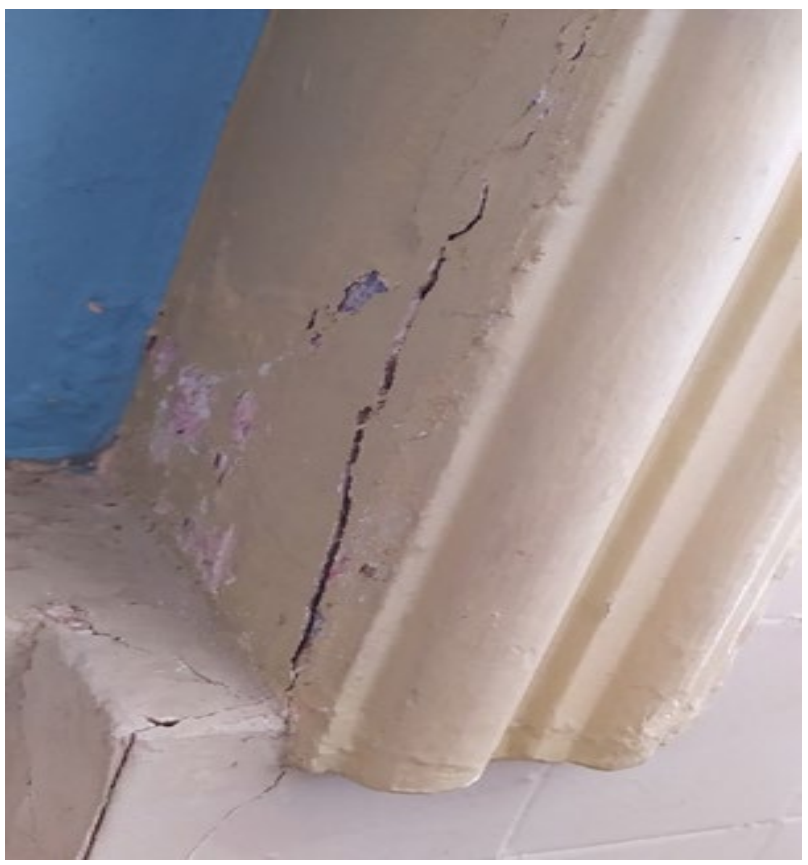

Figura 21- Parede entre os altares de santuários. Lado esquerdo. Patologia: Empolamento da pintura.

Fonte: Os autores, 2021. 
3.2.4- Segundo pavimento.

Ocorrência de trinca (Figura 22)

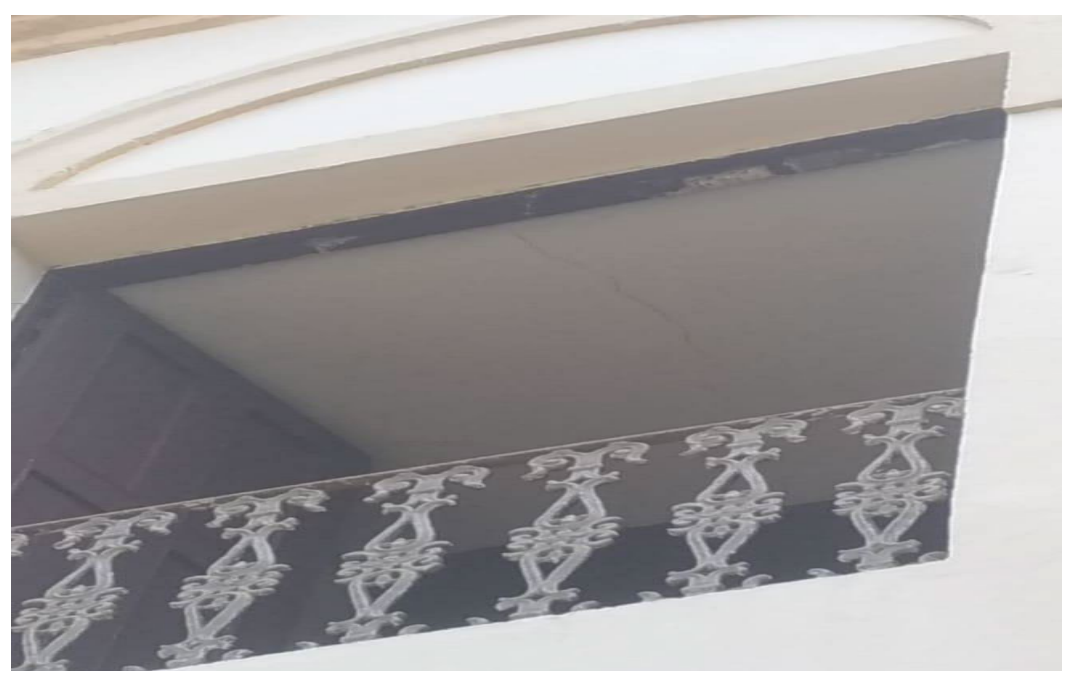

Figura 22 -teto da varanda. Lado direito da vista frontal.

Patologia: fissura

Fonte: Os autores, 2021.

A seguir apresenta-se uma tabela com o levantamento da da quantidade de manifestações patológicas de acordo com o ambiente da estrutura: interno ou externo. Além disso, é representado o número total de acordo com cada manifestação patológica, o ambiente e o total de patologias.

Tabela 1. Mapeamento das principais patologias

\begin{tabular}{|c|c|c|c|}
\hline Patologias & $\begin{array}{c}\text { Casos na } \\
\text { estrutura Externa }\end{array}$ & $\begin{array}{c}\text { Casos na } \\
\text { estrutura Interna }\end{array}$ & Total \\
\hline Fissura & 3 & 5 & 8 \\
\hline Empolamento & 2 & 2 & 4 \\
\hline Umidade & 1 & 0 & 1 \\
\hline Eflorescência & 1 & 1 & 1 \\
\hline Mancha de bolor & 1 & 0 & 1 \\
\hline Trinca & 0 & 1 & 1 \\
\hline $\begin{array}{c}\text { Desprendimento e empolamento de } \\
\text { revestimento de peça cerâmica }\end{array}$ & 0 & 1 & \\
\hline
\end{tabular}




\begin{tabular}{|c|c|c|c|}
\hline Saponificação & 1 & 0 & 1 \\
\hline Total & 9 & 10 & 19 \\
\hline
\end{tabular}

\section{CONCLUSÕES}

Fonte: Os autores, 2021.

Após o levantamento das patologias construtivas existentes na Sé Catedral Nossa Senhora da Penha, pôde-se verificar a frequência de algumas patologias na área interna e externa da edificação. Dentre essas anomalias, destacam-se:

- Infiltrações: As infiltrações são problemas recorrentes dentro da construção civil e a sua reincidência está associada, principalmente, a falhas na impermeabilização. Para a situação encontrada, algumas suposições podem ser feitas: i) mal posicionamento de telhas e encaixes incorretos; estes últimos favorecem a quebra das telhas, permitindo a entrada de água para o forro e às paredes; ii) a falta de impermeabilizantes nas paredes também pode ser uma motivação para a patologia descrita. Para a eliminação desse problema, uma possível solução seria a realização do diagnóstico da presença de umidade no local para sua posterior eliminação, além da remoção do revestimento para aplicação do impermeabilizante;

- Eflorescências: As constantes aparições de eflorescências e suas prováveis causas podem estar associadas à umidade no revestimento argamassado. A entrada de água nessa estrutura pode ocorrer devido a presença de impureza na areia usada na preparação do compósito, deixando-o mais poroso e, além disso, a presença de infiltrações oriundas da falta de impermeabilizantes também permite a entrada de água para o revestimento. Para a resolução dessa problemática, deve ser eliminada a umidade do área afetada por meio da eliminação das infiltrações e aplicação de um impermeabilizante;

- Bolores e Mofos: Essa patologia tem sido frequente dentro da construção civil. Sua incidência também pode ser associada ao contato frequente com a umidade. Porém, outras sugestões para o aparecimento dessa patologia são consideradas como: i) a presença de fissuras na estrutura, pois a fenda originada por essa falha proporciona a entrada de água, permitindo o contato direto da umidade com o revestimento argamassado; ii) a falta de impermeabilização das paredes da igreja, o que permite a entrada de umidade nas camadas de revestimento, provocando a anomalia citada. Para solucionar essa patologia, recomenda-se utilizar hipoclorito na lavagem do local, além de eliminar a infiltração presente;

- Descascamento da pintura: Esta também foi uma patologia muito recorrente na pesquisa de campo. Sua perenidade na estrutura pode ocorrer por diversos motivos, dentre os quais vale destacar: i) a presença de impureza e materiais pulverulentos como prejudiciais à aderência da pintura no reboco; ii) aplicação da tinta em áreas úmidas; iii) uso de materiais de baixa qualidade e iv) falha na preparação da tinta ou execução da pintura sobre caiação. Além disso, essa patologia pode surgir também como consequência do empolamento da pintura, como retratado na figura 16. Para a resolução do problema, o acabamento deve ser removido e renovado de maneira correta;

- Empolamentos: Algumas das possíveis causas dessa patologia são: a presença de impurezas na execução do revestimento argamassado, como materiais orgânicos e 
materiais ferruginosos, além da hidratação tardia do óxido de cálcio ou de magnésio existente no cimento durante a preparação do compósito. Para a resolução desse problema, é necessária a remoção e renovação da camada de revestimento;

- Fissuras: A presença de fissuras é preponderante dentro do cenário construtivo. Na Catedral visitada, verificou-se algumas fissuras no revestimento argamassado, principalmente em quinas e esquadrias. Estabelecer uma causa específica para as mesmas torna-se algo complexo devido à grande variação da manifestação desta patologia nas edificações. Porém, algumas suposições podem ser feitas para a incidência desse problema, dentre as quais temos: i) recalque da edificação, cuja principal manifestação são trincas ou fissuras em formato diagonal; ii) em quinas e esquadrias, a falta de verga e contraverga torna-se um grande fator para o aparecimento dessa mazela construtiva; iii) grande diferença de dilatações dos elementos de alvenaria e dos elementos estruturais como laje, verga e contraverga; iv) falhas no cálculo do projeto ou na execução da estrutura também são motivações comuns para essa patologia, além da preparação errônea da argamassa, a qual pode ter sido feita sem ter a resistência necessária para sua utilização na estrutura. Para a resolução dessa patologia, primeiro deve ser feito um diagnóstico da origem da mesma e, a depender da causa, podem ser utilizados vários métodos de resolução dessa falha, que variam desde a aplicação de um selante simples na fissura, em casos mais simples, até a necessidade de abertura da fissura para sua aplicação, em casos mais sérios;

- Descascamento de placas cerâmicas: Essa patologia possui variados motivos para sua incidência e, contextualizando com a situação verificada na edificação, são sugeridas algumas motivações para o surgimento dessa deterioração. São elas: i) não utilização da junta de assentamento na aplicação do revestimento cerâmico; ii) presença de material pulverulento na área revestida; iii) umidade perene na área afetada; Dentre as variadas formas de solucionar essa mazela construtiva, é possível citar a lavagem do local a ser aplicado o revestimento cerâmico, a retirada das placas defeituosas para aplicação de impermeabilizante para extirpar a umidade presente e a utilização da junta de dilatação na aplicação das placas cerâmicas;

- Saponificação: Esta patologia caracteriza-se pela presença de manchas na pintura e que tem, como consequência, o descascamento da tinta. Na pesquisa de campo, verificou-se algo semelhante e duas prováveis causas para sua aparição são: i) excesso de cal no reboco da edificação e ii) aplicação da tinta antes do tempo de cura do reboco. Uma possível solução para essa deterioração é a raspagem, lavagem e lixação do local visando eliminar partes soltas e sujeiras e, logo após, renovar o acabamento.

\section{AGRADECIMIENTOS}

Os agradecimentos se destinam a todos os autores; ao orientador Aerson Moreira Barreto, que auxiliou na realização do presente trabalho; ao projeto Pacce, por incentivar o estudo colaborativo e ao Padre José Vicente por possibilitar a visita ao local e nos orientar acerca do contexto histórico da Catedral Nossa Senhora da Penha.

\section{REFERÊNCIAS}


Biblioteca Central do IBGE. "IBGE", 2021. Disponível em: https://biblioteca.ibge.gov.br/biblioteca-catalogo.html?id=435160\&view=detalhes. Acesso em: 22 de maio de 2021.

Conselho Federal de Engenharia e Agronomia (CONFEA - Brasil). "Código de Ética do Profissional da Engenharia, da Agronomia, da Geologia, da Geografia e da Meteorologia". Resolução nº 1.002. Brasília: 2019

Pacheco. M, Tutikian, B. (2013). Boletím técnico. Inspección, diagnóstico y prognóstico em la construcción civil. "Unicinos", 2013. Disponível em: https://alconpat.org.br/wpcontent/uploads/2012/09/B1_Inspe\%C3\%A7\%C3\%A3o-Diagn \%C3\%B3stico-eProgn\%C3\%B3stico-na-Constru\%C3\%A7\%C3\%A3o-Civill.pdf. Acesso em: 22 de maio de 2021.

SOUZA, V. C. RIPPER, T. (1998), "Patologia, recuperação e reforço de estruturas de concreto". Pini, São Paulo, Brasil, p. 13.

Yin R. Estudo de caso: planejamento e métodos. 2a ed. Porto Alegre: Bookman; 2001 